\title{
PERLINDUNGAN PRIVASI DATA PRIBADI PERSPEKTIF PERBANDINGAN HUKUM
}

\author{
Fanny Priscyllia \\ Fakultas Hukum Universitas Udayana Denpasar \\ Denpasar, Bali, Indonesia \\ Email: fpriscyllia@gmail.com
}

\begin{abstract}
Abstrak
Perkembangan teknologi informasi dan komunikasi, salah satunya internet (interconnection networking). Informasi berupa data pribadi menjadi acuan dalam penggunaan aplikasi berbasis internet. Privasi data pribadi merupakan hal penting karena menyangkut harga diri dan kebebasan berekspresi seseorang. Perlindungan privasi data pribadi jika tidak diatur dalam suatu peraturan perundang-undangan dapat mengakibatkan kerugian bagi seseorang atas tersebarnya informasi pribadi. Penelitian ini bertujuan untuk menganalisis perlindungan privasi data pribadi dalam perspektif perbandingan hukum. Kajian ini menggunakan penelitian hukum normatif yang meneliti dan menganalisis sumber-sumber hukum. Hasil studi menunjukkan bahwa konsep perlindungan hak privasi merupakan hak penuh seseorang dan pemenuhannya tidak didasarkan pada hak orang lain, tetapi hak tersebut dapat hilang apabila dikehendaki oleh pemiliknya untuk mempublikasikan informasi yang bersifat pribadi kepada publik dan seseorang berhak untuk tidak membagikan semua informasi mengenai pribadinya dalam kehidupan sosial. Ketiadaan hukum yang mengatur secara komprehensif perlindungan privasi atas data pribadi di Indonesia dapat meningkatkan potensi pelanggaran terhadap hak konstitusional warga negara atas perlindungan privasi data pribadi.
\end{abstract}

\section{Kata Kunci: Data Pribadi; Hak Privasi; Perbandingan Hukum.}

\begin{abstract}
The development of information and communication technology, one of which is the internet (interconnection networking). Information in the form of personal data becomes a reference in the use of internet-based applications. Privacy of personal data is important because it involves one's self-respect and freedom of expression. Privacy protection for personal data if not regulated in a statutory regulation can result in loss for someone for the spread of personal information. This study aims to analyze the privacy protection of personal data in the perspective of comparative law. This study uses normative legal research that examines and analyzes legal sources. The results of the study show that the concept of protecting the right to privacy is a person's full rights and fulfillment is not based on the rights of others, but that right can be lost if the owner wishes to publish information that is private to the public and a person has the right not to share all personal information in his life social. The absence of comprehensive laws governing privacy protection for personal data in Indonesia can increase the potential for violations of citizens' constitutional rights to privacy protection for personal data.
\end{abstract}

Keywords: Comparative Law; Personal Data; Privacy Rights.

\section{A. PENDAHULUAN}

Perkembangan teknologi informasi dan komunikasi menunjukkan peningkatan cukup signifikan. Peningkatan kualitas masyarakat Indonesia secara berkelanjutan yang memanfaatkan teknologi informasi serta ilmu pengetahuan merupakan salah satu tujuan pembangunan nasional sekaligus menjadi suatu tantangan global. ${ }^{1}$ Kemajuan teknologi informasi dan komunikasi

${ }^{1}$ Sudaryanti, K. D., Darmawan, N. K. S., \& Purwanti, N. P. (2013). "Perlindungan Hukum Terhadap Invenstor Dalam Perdagangan Obligasi Secara Elektronik”. Kertha Wicara, 2(1), 1-5, hlm. 1 
yang semakin pesat menyebakan perubahan perilaku serta pola pikir yang tanpa disadari oleh masyarakat Indonesia maupun masyarakat global. Perkembangan tersebut menyebabkan "dunia tanpa batas" yang artinya orang dapat mengakses apapun melalui jaringan internet. Perkembangan teknologi informasi dan komunikasi tersebut menimbulkan peluang bahkan tantangan dalam waktu yang bersamaan.

Penggunaan internet (interconnection networking) yang menjadi media informasi dan komunikasi elektronik yang menyediakan beragam aktivitas baik berupa jasa maupun produk seperti e-commerce (perdagangan/bisnis melalui media elektronik), e-education (pendidikan), e-health (kesehatan), e-government (pemerintahan), e-payment (keuangan), transportasi, pariwisata serta perkembangan cloud computing atau komputasi awan yaitu aplikasi yang menyediakan ruang penyimpanan data pengguna seperti google drive, iCloud, Dropbox, Youtube dan sebagainya. Ruang lingkup dari salah satu pembaharuan dalam bidang teknologi informasi dan komunikasi yaitu melakukan pengumpulan, penyimpanan, pembagian, dan penganalisaan data secara efektif dan efisien antar industri/perusahaan atau masyarakat. ${ }^{2}$

Dalam perkembangan teknologi informasi dan teknologi, informasi data pribadi yang terdiri dari nama, $e$-mail, nomor telepon genggam merupakan data yang sangat berharga karena dapat nilai ekonomi yang didapatkan dalam dunia bisnis. Hal tersebut dinamakan digital dossier atau berkas digital yang merupakan kumpulan informasi data pribadi yang dimiliki oleh sebagian besar bahkan hampir seluruh orang dengan memanfaatkan teknologi internet yang dikembangkan oleh pihak swasta yang sangat berisiko terjadinya pelanggaran hak privasi atas data pribadi seseorang. ${ }^{3}$

Peningkatan kebutuhan teknologi informasi dan komunikasi menyebabkan berbagai tindakan kriminal muncul yang dapat mengakibatkan kerugian baik materiil maupun immateriil bagi seseorang. ${ }^{4}$ Meningkatnya aktivitas jumlah pengguna internet menyebabkan isu mengenai perlindungan data pribadi menjadi hal yang serius $\backslash$ karena penyebarannya dapat dilakukan dengan mudah dan cepat melalui teknologi sehingga menimbulkan risiko "bocor"nya data pribadi seseorang. Pada tahun 2011, terjadi pembobolan data pribadi sebanyak 25 juta pelanggan Telkomsel, kemudian hal serupa terjadi lagi pada September 2019 kemarin masyarakat dikejutkan dengan adanya kebocoran data penumpang oleh maskapai penerbangan Lion Air dan Batik Air yang mencapai puluhan juta data. Kebocoran data penumpang termasuk informasi Kartu Tanda Penduduk (KTP) dan nomor paspor penumpang yang diakses dalam ruang penyimpanan (cloud computing) Amazon Web Services (AWS) yang diakses melalui web yang tersimpan dalam filebackup bulan Mei 2019 untuk maskapai Malindo Air dan Thai Lion Air. Kebocoran data tersebut sangat rentan disalahgunakan yang dapat menyebabkan timbulnya beberapa kasus tindakan kriminal misalnya pencurian identitas maupun penipuan apalagi mengingat perkembangan ekonomi modern saat ini kearah digital economy berbasis economy creative, data pribadi termasuk sebagai informasi yang sangat penting bagi para pebisnis. Data Norton Report 2013 mencatat bahwa tingkat potensi dan risiko terhadap tindakan kriminal dalam dunia maya di Indonesia memasuki status darurat dan terus menunjukkan peningkatan

${ }^{2}$ Dewi, S. (2016). “Konsep Perlindungan Hukum Atas Privasi Dan Data Pribadi Dikaitkan Dengan Penggunaan Cloud Computing Di Indonesia”. DEMO 2 JURNAL, (94), 22-30, hlm. 23.

${ }^{3}$ Tejomurti, K., Hadi, H., Imanullah, M. N., \& Indriyani, R. (2018). "Legal Protection for Urban Online-Transportation-User's Personal Data Disclosure in the Age of Digital Technology”. Padjadjaran Journal of Law, 5(3), 485-505, hlm. 487-488

${ }^{4}$ Widyaningrat, I. A. W., \& Dharmawan, N. K. S. (2014). “Tanggung Jawab Hukum Operator Telepon Selular Bagi Pengguna Layanan Jasa Telekomunikasi Dalam Hal Pemotongan Pulsa Secara Sepihak Di Denpasar”. Kertha Semaya: Journal Ilmu Hukum, 2(5), 1-5, hlm. 1.

240 Fanny Priscyllia | Perlindungan Privasi Data Pribadi.... 
yaitu yang dilansir dari laman Id-SIRTII/CC (Indonesia Security Incident Response Team on Internet Infrastructure/Coordination Center) ${ }^{5}$

Konsep perlindungan data pribadi menekankan bahwa setiap orang berhak menentukan nasibnya sendiri seperti apakah dirinya akan melakukan sharing data atau tidak dan apabila sharing data dilakukan maka ia berhak juga menentukan syarat yang hendak dipenuhi dalam suatu komunitas masyarakat. Data pribadi mengenai nama lengkap, e-mail, akun media sosial bahkan nomor rekening dalam berbagai layanan aplikasi yang meminta data pengguna dengan berbagai macam tujuan, salah satunya untuk memastikan data pengguna adalah benar. Tidak ada jaminan bahwa data pribadi tersebut terhindar dari penyalahgunaan. Nomor kontak, nomor rekening bank, alamat rumah dapat menjadi ancaman bagi pemilik data pribadi misalnya penipuan yang dilakukan melalui telepon genggam, menjadi sasaran peretasan rekening bank dan dapat menjadi sasaran perampokan dengan berbagi alamat rumah.

Ketiadaan aturan khusus dalam pengaturan perlindungan data pribadi di Indonesia sehingga diatur pada beberapa peraturan perundang-undangan yang pengaturannya tidak secara komprehensif menekankan pada prinsip-prinsip dari perlindungan data. Menurut Donny B. U sebagai Tenaga Ahli Menteri Komunikasi dan Informasi bidang Literasi Digital dan Tata Kelola Internet menyampaikan bahwa setidaknya terdapat tiga puluh dua (32) undang-undang yang substansinya membahas secara umum mengenai perlindungan data pribadi, contohnya undangundang perbankan yang mengatur perlindungan data pribadi nasabah. Peraturan perundangundangan tersebut masih bersifat parsial dan sektoral, sehingga perlindungan terhadap data pribadi belum optimal dan efektif. Tindakan kriminal yang timbul akibat tersebarnya suatu data pribadi terjadi baik dalam jaringan (daring), misalnya penipuan yang dilakukan melalui media sosial, komputasi awan (computing cloud) maupun diluar jaringan, misalnya pengumpulan data pribadi secara massal (digital dossier), pemasaran langsung (direct selling), dan sebagainya.

Kajian ini jika dibandingkan dengan studi-studi terdahulu memiliki kesamaan dari segi topik yaitu perlindungan privasi atas data pribadi, tetapi berbeda pada pokok analisisnya. Pokok kajiannya adalah membahas dan menganalisis konsep perlindungan privasi atas data pribadi sebagai salah satu hak konstitusional warga negara serta pengaturan privasi data pribadi dalam perspektif perbandingan hukum. Kajian ini bertujuan untuk mengkaji dan menguraikan konsep perlindungan privasi atas data pribadi dan perlindungan privasi data pribadi dalam perspektif perbandingan hukum. Dalam rangka mewujudkan tujuan penulisan maka kajian ini disajikan secara sistematis berdasarkan substansi yang relevan dengan fokus permasalahan yaitu perlindungan privasi atas data pribadi.

Berdasarkan uraian diatas, maka menjadi penting untuk mengkaji secara mendalam isu hukum yang berkaitan dengan bagaimana konsep perlindungan privasi atas data pribadi dan pengaturan mengenai privasi atas data pribadi di Indonesia serta bagaimana pengaturan perlindungan privasi atas data pribadi dibeberapa negara. Kajian ini bertujuan untuk mendisukusikan konsep perlindungan privasi data pribadi serta pengaturannya dalam perspektif perbandingan hukum dibeberapa negara.

\section{B. METODE PENELITIAN}

Jenis penelitian dalam kajian ini adalah penelitian hukum normatif. Penelitian normatif atau penelitian doktrinal (law in books) yang menggambarkan apa yang termuat dalam norma-norma hukum sebagai data rujukan pokok selaku pedoman bertingkah laku yang patut bagi masyarakat. ${ }^{6}$ Objek penelitian dalam penelitian hukum normatif yaitu kekosongan, kekaburan dan konflik

${ }_{5}^{5}$ Latumahina, R. E. (2014). “Aspek Hukum Perlindungan Data Pribadi di Dunia Maya”,Jurnal Gema Aktualita, Vol. 3 No. 2, Desember 2014, 14-25, hlm. 15.

${ }^{6}$ Amiruddin dan Zainal Asikin. (2013). Pengantar Metode Penelitian Hukum. Jakarta: Rajawali Pers, hlm. 118. 
norma. Dalam kajian ini didasarkan pada kekosongan norma pengaturan perlindungan data pribadi sehingga menciptakan ketidakpastian hukum. Jenis pendekatan yang digunakan adalah pendekatan perundang-undangan (the statute approach) yaitu mengkaji aturan hukum terkait isu perlindungan data pribadi, pendekatan konseptual (conceptual approach) yaitu pendapat dan paham-paham yang ada dalam ilmu hukum yang dapat memberikan penjelasan bagi penulis untuk menemukan gagasan-gagasan sehingga menghasilkan pemahaman mengenai konsep dan asas hukum terkait isu yang dikaji yaitu konsep perlindungan data pribadi serta pendekatan komparatif (comparative approach) yaitu perbandingan pengaturan perlindungan data pribadi dalam perpektif perbandingan hukum. Teknik pengumpulan bahan hukum primer yang berpatokan pada hierarki perundang-undangan, bahan hukum sekunder dan bahan hukum tersier baik berupa buku hukum (text book) maupun penerbitan berkala (journal law review) dan kamus. Teknik analisis bahan hukum yaitu penggambaran atau uraian konteks dari postulat hukum yang dianalisis secara deskriptif analitik.

\section{PEMBAHASAN}

1. Konsep Perlindungan Privasi Data Pribadi Dan Pengaturannya Di Indonesia

a. Konsep Perlindungan Privasi Data Pribadi

Pasal 1 angka 1 PeraturanMenteriKomunikasidanInformatika Republik Indonesia Nomor 20 Tahun 2016 tentang Perlindungan Data Pribadi Dalam Sistem Elektronik, memberikan definisi mengenai data pribadi yaitu data seseorang yang disimpan, dirawat, dan dijaga kebenaran serta dilindungi kerahasiaannya. Suatu data disebut sebagai data pribadi ketika berhubungan dengan informasi identitas seseorang atau seseorang dapat diketahui dari data tersebut. Misalnya, Nomor Induk Kependudukan (NIK) yang tertulis dalam kertas adalah data. Tetapi menjadi berbeda jika nomor telepon genggam tersebut dituliskan beserta nama pemiliknya, hal itu menjadi data pribadi. Mengapa demikian? Karena nomor telepon genggam ditulis pada secarik kertas tidak dapat memberikan informasi siapa pemiliknya, tetapi akan berbeda jika dituliskan beserta nama pemiliknya, hal itulah yang disebut sebagai data pribadi. Menjadi hal yang penting bahwa perlindungan data pribadi tidak hanya sebatas apakah suatu data mempunyai identitas atau tidak, tetapi hukum berbicara mengenai perlindungan privasi atas data yang dapat mengidentifikasi pemiliknya.

Konsep privasi bersifatuniversal dandiaturdibeberapanegarabaik dalambentukperaturan perundang-undangan maupun tidak tertulis yaitu aturan yang ada dalam masyarakat (moral). Tahun 1980, Samuel Warren dan Louis Brandeis menjadi pencetus pertama kali mengenai konsep hak privasi. Harvard Law Review menerbitkan sebuah esai yang berjudul "The Right to Privacy", ditulis oleh Samuel dan Louis. Mereka mengungkapkan bahwa pengakuan terhadap hak individu "right to be let alone" merupakan salah satu isu Hak Asasi Manusia (HAM), sehingga Warren menyampaikan gagasannya bahwa privasi merupakan hak setiap individu yang perlu mendapatkan perlindungan kepada hakim. Perlindungan data pribadi menjadi penting karena merupakan hal esensial menyangkut harga diri dan kebebasan berekspresi seseorang. ${ }^{7}$ Pendapat Warren dan Brandies ditanggapi oleh Berzanson bahwa hak privasi atas data pribadi dijadikan sebagai suatu konsep hukum dalam upaya menghargai hak seseorang untuk dapat menikmati kehidupannya sesuai dengan hak yang dimilikinya. ${ }^{8}$ Perlindungan privasi atas data pribadi jika tidak dilindungi maka ketika tersebarnya suatu informasi pribadi seseorang dapat menimbulkan kerugian baik materil maupun immateril.

${ }^{7}$ Dewi, S. (2016). Op.cit, hlm. 25-26.

${ }^{8}$ Bezanson, R. P. (1992). “The Right to Privacy Revisited: Privacy, News, and Social Change”, 1890-1990. California Law Review, 80(5), 1133-1175, hlm. 1134-1135

242 Fanny Priscyllia | Perlindungan Privasi Data Pribadi.... 
Deklarasi Hak Asasi Manusia Association of Southeast Asian Nations (ASEAN) menempatkan perlindungan privasi data pribadi sebagai hak privasi. Saat ini, tercatat 75 negara mengatur perlindungan data pribadi secara khusus. ${ }^{9}$ The Council of Europe Convention for the Protection of Individuals with regard to Automatic Processing of Personal Data (No.108), 1981; the Organization for Economic Cooperation and Development Guidelines on the Protection of Privacy and Transborder Data Flows of Personal Data (1980); the Guidelines for the Regulation of Computerized Personal Data Files (General Assembly Resolution 45/95 and E/CN.4/1990/72); and the General Declaration of Human Rights; the International Convention on Civil and Political Rights; The General Data Protection Regulation (EU) 2016/679 (GDPR) menggantikan The Data Protection Directive 95/46/ $E C$ merupakan aturan-aturan Internasional yang menekankan prinsip-prinsip perlindungan data pribadi yang kemudian diadopsi beberapa negara.Beberapa diantaranya, Personal Data Protection di Argentina, Lawon Protection of Personal and Electronic Document Information di Kanada, Personal Data Protection Law di Jepang, Information Technology Regulation di India, Personal Information Protection Law di Korea Selatan, Data Protection Law di Sungapura, dan Personal Data Law di Filipina dan masih banyak lagi negara-negara yang mengadopsi aturan mengenai perlindungan privasi atas data pribadi dalam European Union Rules dari The Organization for Economic Operation Development (OECD).

Konsep hak privasi dapat dilihat dari perspektifantropologi dan sosiologi yaitu hak privasi sebagai permintaan dari seseorang atau kelompok untuk memutuskan sendiri bagaimana, apa dan kapan informasi mengenai data pribadi seseorang atau kelompok dipublikasikan kepada publik. ${ }^{10}$ Mengapa data pribadi menjadi penting untuk dilindungi? Karena privasi adalah hak penuh seseorang dan pemenuhannya tidak didasarkan pada hak orang lain, tetapi hak tersebut dapat hilang apabila dikehendaki oleh pemiliknya untuk mempublikasikan informasi yang bersifat pribadi kepada publik dan seseorang berhak untuk tidak membagikan semua informasi mengenai pribadinya dalam kehidupan sosial. Berbeda halnya, jika seseorang memberikan informasimengenai data pribadinya kepada publik maka perlindungan privasi atas data pribadi tidak diperlukan karena pemiliknya menghendaki hal tersebut dan tidak merasa keberatan untuk membagikanya kepada publik atau apabila tidak menimbulkan kerugian atas privasi data pribadi maka tidak diperlukan perlindungan privasi atas data pribadi.

Terdapat tiga prinsip penting dalam privasi. Prinsip pertama yaitu "right to be alone" sebagai prinsip dasar privasi seseorang. Ada empat jenis pelanggaran yang timbul dari privasi seseorang yaitu menampilkan seseorang yang bukan pada tempatnya (misalnya menggunakan foto seseorang untuk menggambarkan kekerasan dalam rumah tangga), menampilkan data pribadi seseorang yaitu nama atau nomor telepon dengan tujuan komersial, mempublikasikan "aib" atas data pribadi seseorang kepada publik dan tidak memberikan ruang bagi seseorang untuk sendiri. Prinsip kedua yaitu data pribadi seseorang yang mana informasi data pribadi tersebut ditulis oleh orang lain seperti rekam medis, kebiasaan dari seseorang, informasi pajak, informasi asuransi, informasi catatan kriminal dan sebagainya. Infromasi tersebut dapat disalahgunakan oleh orang yang mengumpulkan atau memproses data itu sebagai pelanggaran atas hak privasi pemiliknya. Prinsip ketiga yaitu privasi atas komunikasi yang dilakukan seseorang dalam daring (online).${ }^{11}$ Dalam kondisi tertentu, penyadapan komunikasi elektronik seseorang oleh orang lain dapat dikategorikan sebagai pelanggaran terhadap hak privasi.

\footnotetext{
${ }^{9}$ Tejomurti, K., Hadi, H., Imanullah, M. N., \& Indriyani, R. (2018). Op.cit, hlm. 492.

${ }^{10}$ Tejomurti, K., Hadi, H., Imanullah, M. N., \& Indriyani, R. (2018). Op.cit, hlm. 493.

${ }^{11}$ Tejomurti, K., Hadi, H., Imanullah, M. N., \& Indriyani, R. (2018). Op.cit, hlm. 493.
} 


\section{b. Pengaturan Perlindungan Privasi Atas Data Pribadi Pada Hukum Indonesia}

Pada tahun 2017 tercatat setidaknya 3.885.567.819 orang didunia yang menggunakan teknologiinternet.Presentasenyamencapai 51,7\%daripopulasiduniayangtelahmelampaui 7,5 miliar. Pada 30 Juni 2017 berdasarkan Data Penggunaan Internet dan Statistik Populasi Dunia mencatat bahwa Asia menempati posisi tertinggi penggunaan internet yaitu 1.938.075.631 pengguna dengan presentase mencapai $50 \%$. Indonesia termasuk didalamnya dengan 1.132.700.000 pengguna internet. ${ }^{12}$

Asosiasi Pengguna Jasa Internet Indonesia (APJII) mencatat bahwa Indonesia menduduki peringkat ke-8 dunia dan peringkat ke-4 se-Asia dalam penggunaan internet. Penggunaan internet di Indonesia mencapai 132,7 miliar dengan presentase 52,5\%pengguna laki-laki dan $47,5 \%$ pengguna perempuan. Pulau Jawa merupakan pulau dengan pengguna terbanyak yaitu 86,3 miliar pengguna. ${ }^{13}$

Perkembangan teknologi informasi dan komunikasi menyebabkan perubahan perilaku, pola pikir serta gaya hidup masyarakat, misalnya pola perilaku yang tak terbatas atau "dunia tanpa batas" dalam hubungan sosial, budaya, ekonomi, serta penegakan hukum. Dalam hal mengumpulkan, menyimpan, dan memproses data yang sebelumnya tidak dapat diprediksi, saat ini menjadi suatu hak yang memerlukan perlindungan atasnya. ${ }^{14}$

Perlindungan privasi data pribadi yang mana telah dinyatakan oleh sejumlah negara sebagai hak konstitusional atau disebut "data habeas" yaitu aturan hukum yang terdapat pada negara-negara tertentu yang bertujuan untuk melindungi data, akun kartu kredit/debit atau pembayaranlainnyadengandetail informasipengguna, fisiologis dankondisikesehatanmental seseorang, rekam medis, dan informasi biometrik, dari pelanggaran atau tindakan kriminal yang dapat ditimbulkan akibat penyalahgunaan data pribadi yang dimiliki oleh seseorang. ${ }^{15}$

Perlindungan hak asasi manusia yang mencakup perlindungan hak privasi dalam hukum Internasional diatur dalamPasal 12 the General Declaration of Human Rights mengatur bahwa seseorangberhakatasperlindunganterhadapsegalabentukancamanyangmenggangguprivasi, keluarga, atau serangan terhadap reputasi dan kehormatan seseorang. Pasal 17 International Convention on Civil and Political Rights juga mengatur perlindungan hak privasi yaitu setiap individu berhak mendapatkan perlindungan dari segala bentuk ancaman terhadap gangguan privasi, keluarga, kehormatan atau reputasi.

Konstitusi Indonesia yaitu Undang-Undang Dasar Negara Republik Indonesia 1945 (selanjutnya UUD RI 1945) pasal 28G mengatur bahwa seseorang memiliki hak perlindungan atas diri pribadi, keluarga, kehormatan, martabat, dan kekayaan serta rasa aman dari segala bentuk ancaman yang ada dari kepemilikannya. Berdasarkan pasal tersebut bahwa setiap orang mendapatkan perlindungan privasi data pribadinya yang didapatkan maupun digunakan oleh orang lain. Penyalahgunaan privasi atas data pribadi merupakan bentuk pelanggaran hak konstitusional.

Penyebaran informasi pada era digital teknologi informasi dan komunikasi saat ini begitu cepat, bersifat global, dan lintas batas negara menjadi tantangan baru yang menyebabkan meningkatnya risiko terhadap pelanggaran hak privasi. Legislasi dan regulasi di Indonesia yang mengatur mengenai data pribadi terdapatsetidaknya dalam 32 undang-undang. Beberapa diantaranya Undang-Undang Republik Indonesia Nomor 36 Tahun 2009 tentang Kesehatan yaitu yang mengatur mengenai data serta kondisi kesehatan pasien atau rekam medis pasien.

\footnotetext{
${ }^{12}$ World Internet Usage and Population Stats, http://www.internetworldstats.com/stats, diakses pada 26 September 2019.

${ }^{13}$ Asosiasi Penyelenggara Jasa Internet Indonesia (APJII). (2016). "Hasil Survei: Penetrasi dan Perilaku Pengguna Internet Indonesia”. Polling Indonesia, hlm. 3.

${ }^{14}$ Tejomurti, K., Hadi, H., Imanullah, M. N., \& Indriyani, R. Op.cit, hlm. 490-491.

6

${ }^{15}$ Greenleaf, G. (2011). "India 's U-turns on data privacy”. Privacy Laws \& Business International Report,(110-114), hlm.
}

244 Fanny Priscyllia | Perlindungan Privasi Data Pribadi.... 
Kemudian Undang-Undang Republik Indonesia Nomor 10 Tahun 1998 tentang Perbankan yang mengatur data pribadinasabah serta transaksi yang dilakukan, Undang-Undang Republik Indonesia Nomor 8 Tahun 1999 tentang Perlindungan Konsumen, Undang-Undang Republik Indonesia Nomor 19 Tahun 2016 tentang Informasi dan Transaksi Elektronik (UU ITE) dan sebagainya. ${ }^{16}$ Serta yang terbaru Peraturan Menteri Kominfo Nomor 20 Tahun 2016 tentang Perlindungan Data Pribadi dalam Sistem Elektronik, tetapi aturan-atturan tersebut belum mengatur secara spesifik dan komprehensif mengenai prinsip-prinsip perlindungan data pribadi sebagai hak konstitusional warga negara.

Tidak terdapatnya suatu aturan khusus perlindungan privasi data pribadi di Indonesia menimbulkan beberapa dampak, salah satunya ketidakpercayaan para investor maupun perusahaan dalam hal "penyimpanan data"nya terhadap Indonesia. Sebaliknya, jika terdapat suatu aturan khusus mengenai privasi atas data pribadi maka dapat memberikan dampak positif misalnya perspektif ekonomi, mendukung Indonesia sebagai pusat bisnis maupun investasi serta manajemen data global dan industri pengelolaan data terpercaya dan kondusif dalam hal penyimpanan data seperti cloud computing yang dapat berkembang di Indonesia.

Ketiadaan aturan hukum yang mengatur secara komprehensif perlindungan privasi data pribadi meningkatkan potensi pelanggaran terhadap hak konstitusional seseorang. Sebagai contoh, program e-health merupakan pelayanan kesehatan berbasis digital teknologi. Program ini memberikan keuntungan berupa kemudahan bagi pengguna tetapi disatu sisi juga memberikan kehawatiran jika tidak didukung oleh suatu peraturan perundang-undangan karena rentan terhadap terjadinya pelanggaran privasi atas data pribadi berupa tersebarnya informasi mengenai pasien yang dapat diakses dan disebarluaskan oleh pihak tertentu dengan tujuan komersial seperti industri obat, industri penyedia jasa, industri asuransi atapun industri lainnya yang terkait.

\section{Pengaturan Privasi Data Pribadi Dalam Perspektif Perbandingan Hukum}

Negara-negara yang mengatur secara khusus privasi atas data pribadi memiliki suatu lembaga pengaws khusus untuk dapat menjamin penerapan dari undang-undangan perlindungan privasi atas data pribadi. Terdapat dua bentuk pendirian lembaga pengawas dalam menjamin penerapan undang-undang yaitu pertama, mendirikan lembaga yang independen, contohnya Malaysia dan kedua, memberikan atau melimpahkan fungsi pengawasan kepada lembaga yang telah ada, contohnya Inggris.

\section{a. Negara-Negara Di Eropa}

Perlindungan privasi atas data pribadi di Uni Eropa diatur sebagai hak dasar warga negara dalam The European Union Charter of Fundamental Rights. Uni Eropa memiliki peraturan perundangan-undangan mengenai data pribadi baru yaitu The General Data Protection Regulation (GDPR). Aturan tersebut sebagai bentuk pemenuhan hak dasar masyarakat Uni Eropa pada era digital saat ini. Bahkan Uni Eropa membentuk sebuah lembaga yaitu The Police Directive sebagai lembaga pengawasan dan perlindungan bagi warga negara dalam hal proses data pribadi serta memberikan sanksi atas setiap pelanggaran penggunaan data pribadi yang dilakukan terhadap pemilik data pribadi. ${ }^{17}$ GDPR menerapkan aturan pengendalian setiap proses informasi data pribadi sebagai standar aturan perlindungan data pada negaranegara Uni Eropa.

Jerman merupakan negara pertama yang mengesahkan undang-undang perlindungan data pada tahun 1970. Pada tahun 1983, Mahkamah Konstitusi Jerman menentukan bahwa setiap

\footnotetext{
${ }^{16} \mathrm{https}$ ://www.hukumonline.com/berita/baca/lt5d1c3962e01a4/perlindungan-data-pribadi-tersebar-di-32-uu--indonesia-perlu-regulasi-khusus/ diakses pada tanggal 26 September 2019.

${ }^{17}$ Rosadi, S. D., \& Pratama, G. G. (2018). “Urgensi Pelrindungan Data Privasi Dalam Era Ekonomi Digital Di Indonesia”. Veritas et Justitia, 4(1), 88-110, hlm. 105
} 
warga negara memiliki hak untuk mengendalikan penggunaan data pribadi dan merumuskan perlindunganprivasiatasdatapribadisebagaibentukhakkonstitusionalwarganegara. Sehingga pemerintah Jerman menaruh perhatian penuh dan menjadi prinsip penting dalam konstitusi pada perlindungan privasi atas data pribadi sebagai hak dasar atas privasi yang dimiliki oleh seseorang.

Pada tahun 1973, Swediamengikutijejak Jerman dengan memberlakukan hukum nasional tentang perlindungan privasi atas data pribadi. Kemudian diikuti oleh Perancis, Swiss, dan Austria pada tahun 1978.

Di Inggris, perlindungan privasi data pribadi diatur dalam Data Protection Act 1998, sebelumnya Data Protection Act 1984 dan mulai diberlakukan pada tahun 2000. Terdapat komisi atau lembaga independen sebagai badan yang mengawasi hak-hak informasi yaitu perlindungan data pribadi dan jaminan perlindungan terhadap hak informasi dalam Privacy and Economic Communication (EC Directive) Regulation 2003, Freedom of Information Act 2000, the Environmental Information Regulation 2004, INSPIRE Regulations, dan ReUse of Public Sector Information Regulation. ${ }^{18}$ Bentuk perlindungan dalam Data Protection Act 1998 mengatur bahwa pengelolaan data pribadi harus mendapatkan persetujuaan serta mencegah adanya pelanggaran penggunaan data yang dapat mendatangkan kerugiaan bagi pemilik data pribadi. Bahkan dalam data Protection Act 1998 diatur bahwa pelarangan mentransfer data pribadi keluar Eropa kecuali negara yang menerima transfer data pribadi menjamin perlindungan data pribadi tidak disalahgunakan. Prinsip-prinsip penting dalam Data Protection Act 1998 yaitu pengelolaan data pribadi harus diperuntukkan sesuai dengan tujuannya yang sah menurut hukum, data pribadi tidak boleh disimpan melebihi jangka waktu tujuannya, proses pengelolaan data pribadi harus sesua dengan hak subjek pemilik data pribadi berdasarkan undang-undang, dan data pribadi tidak boleh dilakukan transfer keluar Uni Eropa kecuali negara penerima data menjamin perlindungan data pribadi tersebut sesuai dengan hak subjek pemilik data dalam proses pengelolaan data pribadinya. ${ }^{19}$

\section{b. Amerika Serikat (United States of America)}

Amerika Serikat tidak memiliki regulasi yang khusus atau tunggal dalam pengaturan perlindungan privasi atas data pribadi. Konsep pelindungan privasi atas data pribadi antara EropadanAmerikamemilikiperbedaan.Konsepperlindungan privasiatasdata pribadipertama kali dicetuskan sekitar tahun 1960. Amerika Serikat mulai memberlakukan aturan hukum perlindungan privasi atas data pribadi pada tahun 1974 yaitu US Privacy Law. Perlindungan privasi data pribadi diatur secara komprehensif dengan pendekatan pencegahan terhadap pelanggaran privasi atas data pribadi atau data sensitif lainnya yang berlaku baik di negara federal maupun di negara-negara bagian. ${ }^{20}$ Terdapat legislasi baru mengenai perlindungan privasi atas data pribadi yaitu California Consumer Privacy Law (CCPA) 2018 yang akan berlaku efektif mulai Januari 2020. Regulasi tersebut menekankan hak privasi yang baru bagi konsumen dan melakukan perubahan program privasi pada perusahaan bisnis di California terkait dengan perlindungan roivasi atas data pribadi.

\section{c. Hongkong}

Hongkong menjadi negara yang pertama kali mengatur secara komprehensif mengenai masalah privasi atas data pribadi di Asia yaitu Personal Data Privacy Ordinance of 1995 (PDPO) yang telah dilakukan perubahan besar pada tahun 2012. Implementasi peraturan

${ }^{18}$ Information Commission Office (ICO), “About ICO” https://ico.org.uk/about-the-ic, diakses pada 30 September 2019.

${ }^{19}$ Latumahina, R. E. (2014). Op.cit, hlm. 18-19.

${ }^{20}$ Dewi, S. (2016). Op.cit, hlm. 26. 
perundang-undangan tersebut dilakukan oleh lembaga khusus penanganan isu privasi data pribadi yang bernama Privacy Commisioner for Personal Data (PCPD).

PrinsipperlindunganhakprivasidatapribadidiHongkongmencakupbatasanpengumpulan data yang dilakukan berdasarkan tujuan pengumpulannya secara sah, penggunaan dan pengungkapan data pribadi harus sesuai dengan tujuannya dan persetujuan dari pemiliknya, kualitas data pribadi yang benar, penyimpanan data pribadi oleh pihak ketiga memiliki batas waktu, pengelola data pribadi diwajibkan untuk melindungi dari akses yang tidak dapat dipertanggungjawabkan, dan keterbukaan "data user" yang digunakan oleh Hongkong yang mewajibkan pihak ketiga pengelola data(organisasi atau perusahaan) untukmempublikasikan kebijakan privasi kepada publik jika dilanggar maka pemerintah Hongkong memberikan surat somasi kepada pihak ketiga yang bersangkutan. ${ }^{21}$

\section{d. Malaysia}

Malaysia memiliki The Personal Data Protection Act No. 709 of 2010 (PDPA Malaysia). Terdapat tujuh prinsip dalam PDPAMalaysia yang diadopsi dari EU Data Protection Directive dari OECD Guidelines atau APEC Framework. Adanya PDPA 2012 di Malaysia maka jaminan keamanan data pribadi dari pengguna internet menjadi meningkat. Karena PDPA Malaysia banyak mengacu pada aturan dalam EU Data Protection Directive dari OECD Guidelines atau APEC Framework, maka Malaysia juga mengatur dalam PDPA bahwa tidak diizinkannya melakukan transfer data pribadi keluar Malaysia kecuali telah mendapatkan izin dari Menteri Informasi, Kebudayaan dan Komunikasi serta negara atau tempat yang menjadi tempat mentransfer data pribadi dapat memberikan jaminan perlindungan data pribadi yang setara dengan PDPA berikan. ${ }^{22}$

\section{e. Singapura ${ }^{23}$}

Singapura memiliki Personal Data Protection Act (PDPA) 2012. Pengaturan mengenai data pribadi di Singapura berlaku penuh sejak tahun 2014. Aturan mengenai data pribadi antara Malaysia dan Singapura memiliki banyak kesamaan karena keduanya mengadopsi aturan yang terdapat dalam European Data Protective Directive (EUDP). Tetapi terdapat perbedaan dalam aturan milik Malaysia dan Singapura yaitu PDPA 2012 milik Singapura dilengkapi dengan sebuah badan khusus pendaftaran nomor telepon bernama Do Not Call (DNC) Registry, dimana masyarakat memiliki hak untuk menerima maupun menolak pesan singkat (SMS atau MMS) dari pihak ataupun organisasi marketing yang tidak diinginkan.

\section{f. Korea Selatan}

Perlindungan privasi atas data pribadi di Korea Selatan diatur dalam Personal Information Protection Act (Pipa) 2011. Prinsip perlindungan privasi atas data pribadi yang dimiliki Korea Selatan tidak berbeda jauh dengan aturan yang dimiliki oleh Hongkong yaitu tujuan yang jelas dalam proses pengumpulan data pribadi (dipastikan akurat, lengkap dan benar) yang digunakan sesuai dengan tujuannya, menjaga keamanan data pribadi dan pengelolaan data pribadi yang tidak boleh melanggar hak yang bersangkutan sesuai dengan ketentuan hukum. ${ }^{24}$

\section{g. Jepang}

Jepang telah memiliki regulasi perlindungan privasi data pribadi sejak tahun 2000. Data Protection Art merupakan aturan hukum yang diadopsi oleh Pemerintah Federal Jepang. Perumusan aturan hukum terkait dengan perlindungan privasi atas hak pribadi dicetuskan oleh Keidanren yaitu representatitve body yang secara khusus mengatur mengenai permasalahan industri dan perdagangan di Jepang. Pengaturan data pribadi sebagai bentuk perlindungan

\footnotetext{
${ }^{21}$ Greeneaf, Graham. (2014). Asian Data Privacy Laws-Trade and Human Rights Perspectives. New York: Oxford University Press, hlm. 80 .

${ }^{22} \mathrm{Ibid}$, hlm. 320-328.

${ }^{23}$ Latumahina, R. E. (2014). Op.cit, hlm. 19.

${ }^{24}$ Latumahina, R. E. (2014). Op.cit, hlm. 329-337.
} 
pemerintah Jepang dalam era persaingan dagang di Uni Eropa maka lahirlah Data Protection Art. ${ }^{25}$ Prinsip-prinsip perlindungan data pribadi dalam Data Protection Art yaitu data pribadi bersifatrahasia, pemilik data pribadi yang tercatatmengetahui dengan pastitujuan penggunaan datapribadinyaoleh pihakmanapun, terdapatpersetujuanberupa privacypolicy sebagaibentuk penggunaan data yang tidak sesuai dengan persetujuan, pemilik data pribadi berhak untuk melakukan perubahan maupun perbaikan data pribadinya, dan apabila terjadi pelanggaran penggunaan data pribadi maka diharuskan adanya pemulihan kembali atau ganti rugi yang diakibatkan oleh pelanggaran yang ditimbulkan dikemudian hari.

\section{KESIMPULAN}

Konsep perlindungan privasi data pribadi yaitu "right to be alone" sebagai prinsip dasar privasi seseorang. Privasi data pribadi sebagai hak konstitusional setiap warga negara sehingga pengaturannya merupakan bentuk penghargaan dan perlindungan atas hak tersebut. Perlindungan privasi data pribadi dalam peraturan perundang-undangan secara khusus diperlukan bagi Indonesia. Pengaturan data pribadi di Indonesia diatur secara umum dalam beberapa peraturan perundang-undangan kurang lebih tiga puluh dua (32) peraturan perundangundangan Pengaturan perlindungan privasi atas data pribadi dapat berdampak positif, salah satunya adalah meningkatkan nilai ekonomi Indonesia dalam marketplace dunia. Perlindungan privasi data pribadi dalam perspektif perbandingan hukum, menempatkan hak privasi sebagai salah satu hak konstitusional warga negaranya sehingga bentuk penghargaan dan perlindungan terhadap hak konstitusional itu diatur secara khusus serta membentuk atau menunjuk suatu lembaga pengawas khusus untuk dapat menjamin penerapan dari undang-undang perlindungan privasi data pribadi tersebut. Hal itu patut menjadi acuan bagi Indonesia dalam pembentukan aturan hukum terhadap privasi data pribadi yaitu salah satunya membentuk suatu lembaga khusus atau menunjuk suatu lembaga dalam pengawasan terhadap segala bentuk pelanggaran privasi data pribadi di Indonesia.

\section{DAFTAR PUSTAKA}

\section{Buku}

Amiruddin dan Zainal Asikin. (2013). Pengantar Metode Penelitian Hukum. Jakarta: Rajawali Pers.

Asosiasi Penyelenggara Jasa Internet Indonesia (APJII). (2016). Hasil Survei: Penetrasi dan Perilaku Pengguna Internet Indonesia. Polling Indonesia.

Greeneaf, Graham. (2014). Asian Data Privacy Laws-Trade and Human Rights Perspectives. New York: Oxford University Press.

\section{Jurnal}

Bezanson, R. P. (1992). “The Right to Privacy Revisited: Privacy, News, and Social Change,1890-1990”. California Law Review, 80(5), 1133-1175.

Dewi, S. (2016). “Konsep Perlindungan Hukum Atas Privasi Dan Data Pribadi Dikaitkan Dengan Penggunaan Cloud Computing Di Indonesia”. DEMO 2 JURNAL, (94), 22-30.

Greenleaf, G. (2011). “India’s U-turns on data privacy”. Privacy Laws \& Business International

\footnotetext{
${ }^{25}$ Indriyani, M. (2017). "Perlindungan Privasi dan Data Pribadi Konsumen Daring Pada Online Marketplace System". Justitia Jurnal Hukum, 1(2), 191-208, hlm. 202-203
}

248 Fanny Priscyllia | Perlindungan Privasi Data Pribadi.... 
Report,(110-114).

Indriyani, M. (2017). "Perlindungan Privasi dan Data Pribadi Konsumen Daring Pada Online Marketplace System”, Justitia Jurnal Hukum, 1(2), 191-208.

Latumahina, R. E. (2014). “Aspek Hukum Perlindungan Data Pribadi di Dunia Maya”, Jurnal Gema Aktualita, Vol. 3 No. 2, Desember 2014, 14-25

Tejomurti, K., Hadi, H., Imanullah, M. N., \& Indriyani, R. (2018). "Legal Protection for Urban OnlineTransportation-User's Personal Data Disclosure in the Age of Digital Technology”'Padjadjaran Journal of Law, 5(3), 485-505.

Rosadi, S. D., \& Pratama, G. G. (2018). "Urgensi Perlindungan Data Privasi Dalam Era Ekonomi Digital Di Indonesia”'Veritas et Justitia, 4(1), 88-110.

Sudaryanti, K. D., Darmawan, N. K. S., \& Purwanti, N. P. (2013). "Perlindungan Hukum Terhadap Invenstor Dalam Perdagangan Obligasi Secara Elektronik.Kertha Wicara, 2(1), 1-5.

Widyaningrat, I. A. W., \& Dharmawan, N. K. S. (2014). “Tanggung Jawab Hukum Operator Telepon Selular Bagi Pengguna Layanan Jasa Telekomunikasi Dalam Hal Pemotongan Pulsa Secara Sepihak Di Denpasar”. Kertha Semaya: Journal Ilmu Hukum, 2(5), 1-5.

\section{Internet}

Information Commission Office (ICO), “About ICO”. Availabe from: https://ico.org.uk/aboutthe-ic, diakses pada 30 September 2019.

World Internet Usage and Population Stats. Available from: http://www.internetworldstats. com/stats, diakses pada 26 September 2019.

https://www.hukumonline.com/berita/baca/lt5d1c3962e01a4/perlindungan-data-pribaditersebar-di-32-uu--indonesia-perlu-regulasi-khusus/ diakses pada tanggal 26 September 2019. 